Sepúlveda, L.R., Fernandez, J.P., Vera-Piombo, M., Chaar, F.B., \& Rubilar, T. (2021). Photoperiod in aquaculture of the sea urchin Arbacia dufresnii (Echinodermata: Echinoidea): Effects on gamete production and maturity. Revista de Biología Tropical, 69(S1), 464473. DOI 10.15517/rbt.v69iSuppl.1.46386

DOI 10.15517/rbt.v69iSuppl.1.46386

\title{
Photoperiod in aquaculture of the sea urchin Arbacia dufresnii (Echinodermata: Echinoidea): Effects on gamete production and maturity
}

\author{
Lucas R. Sepúlveda ${ }^{1,2}$ \\ Jimena Pía Fernandez ${ }^{1,2}$ \\ Mercedes Vera-Piombo ${ }^{1,2}$ \\ Florencia Belén Chaar ${ }^{2,3}$ \\ Tamara Rubilar ${ }^{1,2 *}$
}

1. Biological Oceanography Laboratory, Centro para el Estudio de Sistemas Marinos, Centro Nacional Patagónico, Consejo Nacional de Investigaciones Científicas y Técnicas, Bv. Alte. Brown 2915, Puerto Madryn, Argentina; 1sepulveda@cenpat-conicet.gob.ar,jpfernandez@cenpat-conicet.gob.ar, mercedes.verapiombo@gmail.com

2. Laboratory of Chemistry of Marine Organisms. Instituto Patagónico el Mar. Faculty of Natural Sciences and Health Sciences. National University of Patagonia San Juan Bosco. Puerto Madryn. Argentina; rubilar@cenpat-conicet.gob.ar (*Correspondence).

3. National University of Patagonia San Juan Bosco, Bv. Alte. Brown 3051, Puerto Madryn, Argentina; chaar@gmail.com

Received 17-VII-2020. Corrected 25-VIII-2020. Accepted 05-X-2020.

\begin{abstract}
Introduction: Photoperiod is, together with temperature and food availability, one of the main stimuli in the regulation of gametogenesis in a wide variety of species. Objective: To evaluate the effect of photoperiod on the production of mature gametes in cultured Arbacia dufresnii. Methods: An experiment was carried out with three varying light-dark regimes/treatments: constant light ( $24 \mathrm{~h} \mathrm{light})$, neutral photoperiod $(12 \mathrm{~h} \mathrm{light,} 12 \mathrm{~h}$ darkness), and constant darkness ( $24 \mathrm{~h}$ darkness). Twenty females were used in each treatment. All were induced to spawn and, ten randomly selected females from each treatment were induced to spawn again after 30 days. After 60 days, spawning was induced in the remaining females. The gametes were collected in filtered seawater, fixed in Davidson solution, quantified and measured per individual in triplicate in a Sedgewick-Rafter chamber. To determine maturation, fertilization success was evaluated 30 minutes after fertilization. Results: Our results showed that in the aquaculture system, after only two months, mature gametes were obtained, and in the neutral light regime there were 10 times more gametes than the number produced in wild sea urchins during the spawning period in question. We also found that with a greater exposure to light, a lower number of mature gametes was produced. Conclusions: This study suggests the viability of the production of mature gametes in a short period of time as regards Arbacia dufresnii.
\end{abstract}

Key words: gonad productivity; echinoderm; echinoid; aquaculture; mature gametes.

Sea urchin aquaculture is carried out for a variety of purposes in different parts of the world. The most common purpose of this activity is aimed at the gastronomic industry, that is, the human consumption of sea urchin gonads.
However, aquaculture practices also take place with the aim of enhancing the quality of the gonads of wild individuals (Pearce, Daggett, \& Robinson, 2004; Walker et al., 2015; Rubilar et al., 2016), as well as with the aim of producing 
juveniles that can repopulate populations (Cárcamo, 2004) and, last but not least, with the aim of being used as model organisms in developmental studies (Harris \& Eddy, 2015; Unuma, Sakai, Agatsuma, \& Kayaba, 2015). In addition, the development of technology for the production of marine non-food organisms has taken place globally, and there is, today, a broad range of applications, including, for example, nutraceutical, cosmeceutical, pharmaceutical, biofuel, and conservation products. (Costa-Leal, Rocha, Rosa, \& Calado, 2016). In Argentina, there is a startup with a focus on the non-traditional species in aquaculture, Arbacia dufresnii, aiming to produce mature gametes with a high concentration of pigments and fatty acids for application in nutraceutical, cosmeceutical, pharmaceutical and veterinary products (www.arbacia.com.ar). Arbacia dufresnii is a temperate and abundant sea urchin species with a wide distribution in South America, from Río de la Plata in Argentina (35 $\mathrm{S}$ ) on the Atlantic coast to Puerto Montt in Chile $\left(42^{\circ} \mathrm{S}\right)$ on the Pacific coast, at a depth range of 0-315 m (Brogger et al., 2013). The species is a summer spawner with two peaks of spawning activity, one partial peak in the austral spring (September-October) and another major peak at the end of austral summer (March) (Brogger, Martinez, \& Penchaszadeh, 2010; Epherra et al., 2014). The species was previously studied to assess whether its gonadal quality could be improved through aquaculture methods, demonstrating the possibility to modify the production of the gonadal mass and the composition of cell content through the use of formulated feed (Rubilar et al., 2016).

Eggs are the final product of gametogenesis in the female sea urchin. This process involves the accumulation of nutrients, the proliferation of oogonium, the differentiation of gametes, maturation of gametes and, finally, the spawning of gametes. Frequently, there is a period of quiescent reabsorption of the residual gametes and, then, the process starts all over again (Mercier \& Hamel, 2009; Walker, Lesser, \& Unuma, 2013; Epherra et al., 2014). There is a control mechanism in the gametogenic cycle triggering the end of the resting period and the subsequent re-starting of gametogenesis. This control is thought to be determined by both endogenous and exogenous factors (Mercier \& Hamel, 2009). In sea urchins, gametogenesis is initiated in response to external factors, such as temperature and photoperiod (Fuji, 1967; Pearse \& Walker, 1986; Bay-Schmidt \& Pearse, 1987; Byrne, 1990; Unuma, Konishi, Furuita, Yamamoto, \& Akiyama, 1996; Meidel \& Scheibling, 1998; Walker \& Lesser, 1998; Spirlet, Grosjean, \& Jangoux, 2000; Unuma, 2002; Kirchhoff, Eddy, \& Brown, 2010; Gianguzza, \& Bonaviri, 2013; Wangensteen, Turon, Casso, \& Palacín, 2013; Díaz-Martínez, Carpizo-Ituarte, \& Benítez-Villalobos, 2019). To be successful, any sea urchin aquaculture must take into account the factors regulating gametogenesis. In addition, the majority of sea urchins have annual reproductive cycles (Marzinelli, Bigatti, Giménez, \& Penchaszadeh, 2006; Walker et al., 2013; Epherra et al., 2014) which constraints the period of exploitation to a narrow annual season which has to be well controlled in order to harvest the gonads at the appropriate time. Various strategies have been proposed to extend the harvest season for high quality gonads by focusing on the prolongation of the growth period of the nutritive phagocytes and/or by delaying gametogenesis (Unuma \& Walker, 2010). Due to the fact that the photoperiod and temperature can be manipulated in aquaculture, such manipulation can be used to promote, or delay, gonad development (Walker \& Lesser, 1998; Spirlet et al., 2000; Pearce, Daggett \& Robinson, 2002; Kirchhoff et al., 2010). All of the research undertaken to manipulate gametogenesis in sea urchin aquaculture is aimed at generating the gonadal production of good quality for the gastronomic market. One of the key factors in the quality of gonads is the presence of fewer gametes relative to somatic cells (Unuma \& Walker, 2010). In this sense, sea urchin aquaculture could produce market quality gonads for a longer period during the year and could replace the wild-harvested sea urchins. To do so, there are two strategies to extend the period in which 
gonads are harvested in the aquaculture system: to extend the period of somatic cells, or to suppress gametogenesis (Walker et al., 2015). However, the $A$. dufresnii aquaculture system incorporates a completely different strategy. Here, the goal is to obtain the largest number of mature gametes in the shortest period possible in order to harvest mature gametes several times during the year.

In this context the manner in which the photoperiod affects this species gametogenesis is, still, unknown. The aim of the present work is to evaluate the effect of photoperiod on gamete production and maturation in the $A$. dufresnii aquaculture system.

\section{MATERIALS AND METHODS}

Collection of sea urchins: Adults sea urchins $(\overline{\mathrm{x}}=30.69 \pm 2.52$ S.D. mm diameter $)$ were collected $(\mathrm{N}=120)$ on July 1, 2019 from Nuevo gulf (42 $46^{\prime} 44^{\prime \prime}$ S \& 64'59'52”'W) and transported to the Experimental Aquarium at Centro Nacional Patagónico, Consejo Nacional de Investigaciones Científicas y Técnicas (CENPAT-CONICET) in Puerto Madryn, Argentina.

Experimental design: A week after collection (on July 7) and without being fed to ensure depletion of the gut and to standardize the nutritional status of all individuals (Watts, Lawrence, \& Lawrence, 2013), the sea urchins were placed and distributed into three aquaria $(\mathrm{N}=20$ per aquarium) and three different lightdark regimes (treatments) were established: Constant Darkness (CD $=24$ hours of daily darkness), Neutral Photoperiod (NP $=12$ hours of light and 12 hours of darkness), and Constant Light ( $C L=24$ hours of daily light). Each aquarium was 901 in volume, with a semiclosed aquaculture recirculating system. The seawater was pumped through a decanter, a physical filter, a biofilter and then recirculated into the aquaria. Extra air pumps were placed in each aquarium to ensure good oxygenation of the water. Twenty-five percent of the water volume was changed twice a week, and in conjunction with this, any feces and uneaten feed was siphoned off, and the animals were also fed at this time, that is, twice a week. The water quality was maintained within the optimal parameters and checked every week on the basis of an aquarium test (Tetra) at a salinity of 35 ppt and a temperature between $14{ }^{\circ} \mathrm{C}$ and 16 ${ }^{\circ} \mathrm{C}$ (similar values as those found in field conditions). The sea urchins were fed every three days with a weighed amount of formulated feed (500 mg per individual) (Table 1) produced by the Group for Research and Technological Development in Aquaculture and Fisheries (GIDTAP) at the National Technological University (UTN).

TABLE 1

Composition of the formulated feed

\begin{tabular}{lc}
\multicolumn{1}{c}{ Ingredients } & $\begin{array}{c}\text { Percentage weight } \\
\text { (as is or as fed basis) }\end{array}$ \\
Wheat Starch & $4 \%$ \\
Cornstarch & $19 \%$ \\
Soy protein & $11 \%$ \\
Lecithin & $0.6 \%$ \\
Marine Ingredients & $36 \%$ \\
Non-Marine Ingredients & $28.2 \%$ \\
Vitamin premix & $0.6 \%$ \\
Minerals premix & $0.6 \%$ \\
\hline
\end{tabular}

To determine the sex of the individuals, each sea urchin was induced to spawn their gametes at the beginning of the experiment. For the induction of spawning, sea urchins were injected with $0.3 \mathrm{ml}$ of $0.55 \mathrm{M} \mathrm{KCl}$ solution (Strathmann, 1987). Only females were selected for the experiment as the production of mature eggs was the focus of the study. Males sea urchins were introduced into the broodstock of the experimental aquarium at the Centro Nacional Patagónico. After 30 days, ten random females were selected and once again, spawning was induced. After 60 days, the experiment was finalized and spawning was induced in the remaining females. The gametes were collected on filtered seawater, fixed in a Davidson solution, photographed and quantified per individual in triplicate in a Sedgewick-Rafter chamber using a Leica 
DM 2500 microscope, Leica ICC50W digital camera and LAS EZ B4.5.0.418 software. Using the Image-J program, the female gametes were measured.

The maturity of the gametes was assessed on the basis of fertilization success, for this purpose gametes from five females from each treatment were fertilized. Sperm was obtained from males of the broodstock. Fertilization was carried out by using a 1:100 $000 \mathrm{v} / \mathrm{v}$ dilution of sperm (Fernández, Epherra, Sepúlveda, \& Rubilar, 2019). After 30 minutes, the fertilization success was verified under microscope by observing the fertilization membrane in the eggs (Fig. 1). The percentage of fertilized eggs was calculated.

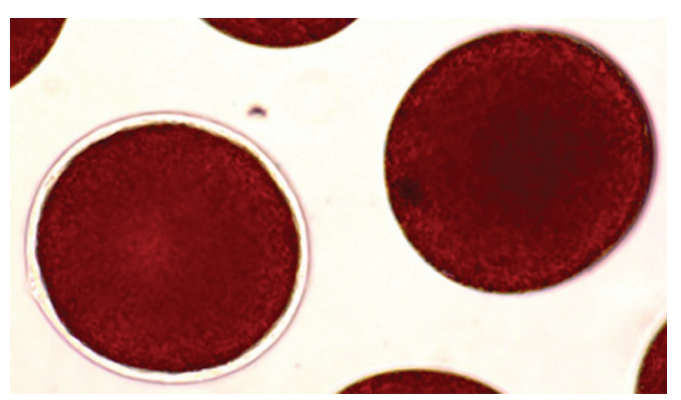

Fig. 1. Fertilized egg with the fertilization membrane (left) and unfertilized egg (right).

Data analysis: Comparisons between the quantity of gametes produced for each treatment was made using Primer v7.0.13 (Primer-E, Quest Research Ltd). Data were untransformed, converted into similarity matrices using Bray-Curtis distances. Multivariate two-way permutational analysis of variance (PERMANOVA) was performed in Primer v7.0.13 with the PERMANOVA +1 add-on (Anderson, Gorley, \& Clarke, 2008). Significant differences of PERMANOVA routine comparing distances between centroids in treatments and time, resulted in further analysis using a similarity percentages (SIMPER) routine. The PERMANOVAs were conducted using Type III (partial) sums of squares, treatment as fixed effects, and time as random effects with 9999 permutations using unrestricted permutation of the raw data. For pairwise tests where there were $<20$ unique permutations, the Monte Carlo P-value was used, as recommended in Anderson et al. (2008). Fertilization success was performed applying a one-way analysis of variance (ANOVA). The ANOVA assumptions were tested and all of the statistical analyses were carried out using the Statistica software (version 7).

\section{RESULTS}

The number of gametes changed significantly during time and treatments. There was no interaction between time and treatments (Table 2). The SIMPER analysis showed that total gametes had $>65 \%$ dissimilarity over time. At the beginning of the experiment, the number of gametes per female was between 250000 and 450000 . After 30 days of treatment, the number of gametes per female increased in every treatment from 400000 to 700000 gametes. At this point, the sea urchins in the neutral photoperiod treatment (NP) showed the highest total number of gametes per female. At the end of the experiment, after 60 days of the different light regimes, the total number of gametes per female increased notably, up to 3500000 gametes. The treatment with constant darkness (CD) resulted in the lower value, with a median of 1395000 gametes. The SIMPER analysis showed that total gametes in the CD treatment had $38 \%$ of gametes that constant light (CL) treatment, and NP treatment had $62 \%$ of gametes that CL (Fig. 2, Table 2).

The maturity of gametes was affected by the light regime applied. After 30 days of experiment, sea urchins in the neutral photoperiod treatment showed the lowest fecundity success rate, less than $15 \%\left(\mathrm{~F}_{2}=10.03, \mathrm{P}=\right.$ $0.0003)$. After 60 days under light regimes, the fecundity success rate increased in all of the treatments and showed significant differences $\left(\mathrm{F}_{2}=3.28, \mathrm{P}=0.044\right)$. NP evidenced the highest maturity of gametes, with $94 \%$ fecundity success rate, and the CL treatment resulted in 
TABLE 2

PERMANOVA of total number of gametes in relation to the light regime (treatment) and time (day)

\begin{tabular}{lccccc}
\multicolumn{1}{c}{ Factor } & S.S. & D.F. & M.S. & Pseudo-F & P (perm) \\
Time & 66892 & 2 & 33446 & 29.143 & 0.0001 \\
Treatment & 5180.4 & 2 & 2590.2 & 4.5599 & 0.00328 \\
Day*Treatment & 2170.4 & 4 & 542.6 & 0.47279 & 0.911 \\
Residuals & $1.2624 \mathrm{E}+05$ & 110 & 1147.7 & & \\
\hline
\end{tabular}
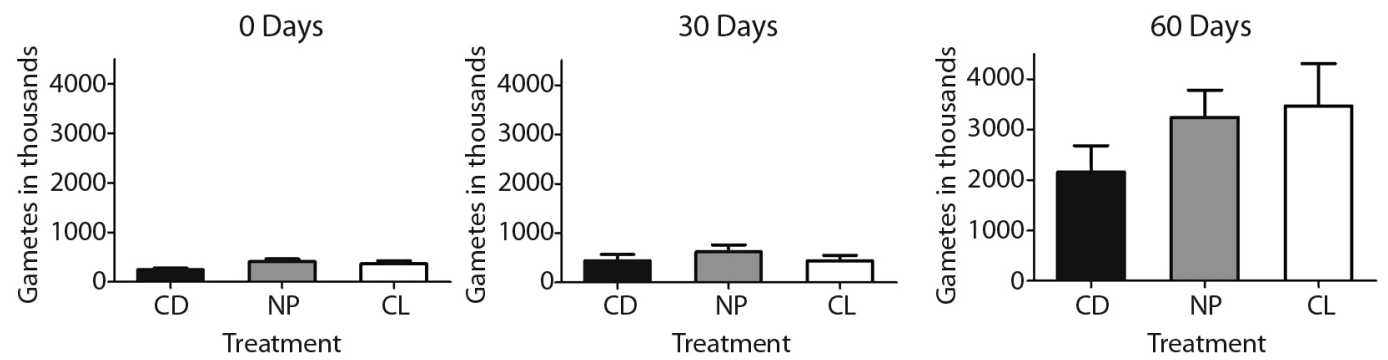

Fig. 2. Total gametes spawned in order of thousands through time period and light-darkness regimes in Arbacia dufresnii. $\mathrm{CD}=$ Constant darkness. $\mathrm{NP}=$ Neutral photoperiod. $\mathrm{CL}=$ Constant light.

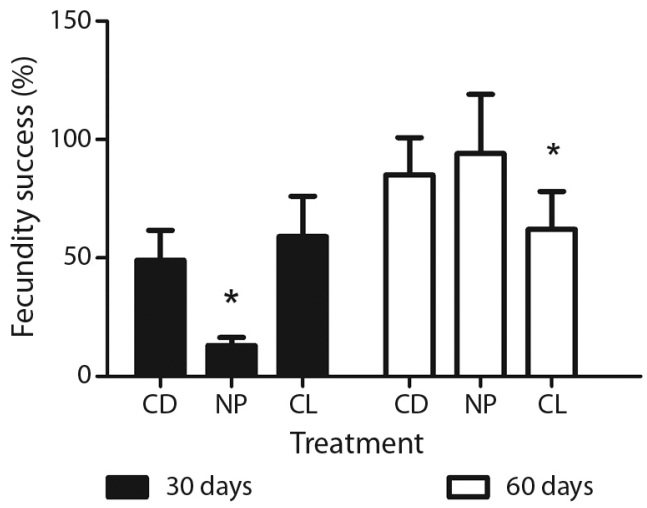

Fig. 3. Fecundity success after 30 and 60 days of light treatment as regards Arbacia dufresnii. $\mathrm{CD}=$ Constant darkness. $\mathrm{CL}=$ Constant light. $\mathrm{NP}=$ Neutral photoperiod. The * refers to the treatments showing significant differences.

the lowest value, with $64 \%$ fecundity success rate (Fig. 3).

The egg diameter showed that by the end of the experiment, all of the light regimes presented mature gametes $(>50 \mu \mathrm{m})$. However, the NP treatment also showed a few immature gametes, more so than with the other treatments (Fig. 4).

\section{DISCUSSION}

The manipulation of gametogenesis in aquaculture is not a new concept, in fact it is widely used to control reproductive timing in a number of different aquacultured fish and invertebrate species (Devauchelle \& Mingant, 1991; Bromage, Porter, \& Randall, 2001). The generation of an "out of season" or "permanent" harvest season in sea urchin aquaculture is a main goal (Walker \& Lesser, 1998). Using photoperiod to modify sea urchin gametogenesis is not a novel idea; however, it can produce a variety of effects. For example, in Strongylocentrotus droebachiensis in the U.S., it was possible to manipulate the production of mature gametes by maintaining the spring light regime (12L:12D). Here it should be stated that the reproductive cycle was advanced by six months. Viable gametes could not be produced in a large number prior to nine months (Kirchhoff et al., 2010). In the same species in Norway, in an aquaculture system, sea urchins were able to produce mature gametes over a six months period by simulating a summer photoperiod (James, Siikavuopio, \& Mortensen, 

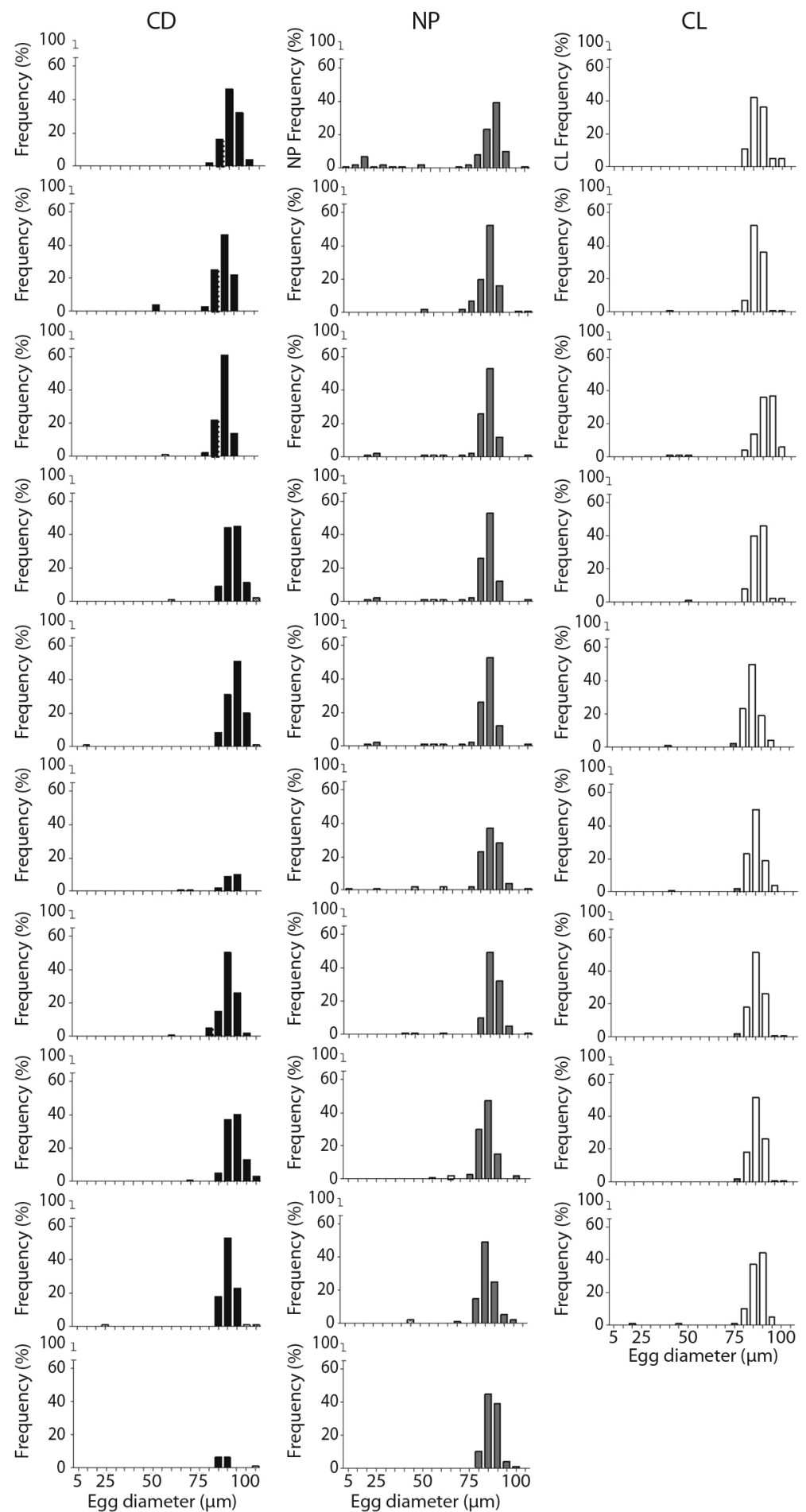

Fig. 4. Egg diameter of day 60 of light/darkness treatment in Arbacia dufresnii. $C D=$ Constant darkness. NP $=\mathrm{Neutral}$ photoperiod. $\mathrm{CL}=$ Constant light. Each figure represents an individual. 
2015). In Paracentrotus lividus, an advanced photoperiod, in combination with a constant temperature, was used successfully to promote "out of season" gonadal maturation. However, this required at least three months and there is no information as to whether the gametes were mature (Kelly, Carboni, Cook, \& Hughes, 2015). In addition, constant darkness reduced the gonad production (McCarron, Burnell, \& Mouzakitis, 2010), as we also found in our study. In populations of the same species in Israel, long day treatments were able to delay gametogenesis in comparison with darkness and shorter days (Shpigel, McBride, Marciano, \& Lupatsch, 2004). In Strongylocentrotus purpuratus, oogenesis can be inhibited by long days (16L:8D) and activated by short days (8L:16D) and a neutral photoperiod (12L:12D) (Bay-Schimith \& Pearse, 1987). In Eucidaris tribuloides, a tropical species, the change in the photoperiod was the key to producing out of season gametogenesis and to increasing the number of gametes. Shorter days were more effective (9L:15D) (McClintock \& Watts, 1990). The females of Psammechinus miliaris are incapable of completing gametogenesis in short photoperiods and the photoperiod appears to be the primary stimulus for gametogenesis (Kelly, 2001). As regards Tripneustes gratilla, a private Australian company, a spin-off from research activity at Macquarie University, was able to maintain sea urchins at a specific reproductive stage through manipulation of the photoperiod (Vaïtilingon \& Williamson, 2008). In spite of this, not every species seems to be influenced by the photoperiod in this manner. For example, Loxechinus albus in the Beagle Channel showed a negative correlation with photoperiod (Pérez, Boy, Morriconi, \& Calvo, 2010). Pseudechinus magellanicus, a species coexisting with $A$. dufresnii, also showed a negative correlation with the photoperiod (Marzinelli et al., 2006). In the aquaculture of Strongylocentrotus intermedius in Japan, photoperiod manipulation is not used to promote gametogenesis, as temperature seems to be the most important factor (Musgrove, 2005; Unuma et al., 2015), and, in China, photoperiod control is not widely used to condition sea urchin aquaculture (Liu \& Chang, 2015).

Wild A. dufresnii start the gametogenesis during autumn (April-May) when the days are shortening, followed by spawning during the spring and summer when there are lengthening days. A positive correlation between gonad weight and photoperiod was previously suggested (Brogger et al., 2010; Epherra et al., 2014). Surprisingly, in aquaculture systems of A. dufresnii, only two months are needed to develop mature gametes regardless of the light regime. In this study, the highest quantities of gametes were found at constant light; however, only the sea urchins with a neutral photoperiod evidenced mature gametes in excess of $90 \%$. The constant light treatment diminished the fecundity success rate by $30 \%$ and also generated a problem with the seawater quality as water exchange and cleaning had to be undertaken more often due to the growth of microalgae. Constant darkness, on the other hand, even though it produced mature gametes, resulted in an amount of gametes equivalent to $50 \%$ of the amount produced by the other light regimes. This indicates that periods of darkness are needed to successfully generate gametes in good numbers in A. dufresnii. We present the first study on the effect of photoperiod on fecundity in the sea urchin A. dufresnii. Our results suggest that the reproductive cycle of this species can be altered by modifying the photoperiod. We found that by using a 12L:12D photoperiod in the aquaculture system, mature gametes were obtained in only two months, and the number of gametes was almost 10 times in excess of the amount produced by wild sea urchins. This study suggests the feasibility of the production of mature gametes in a short period of time in the novel aquaculture species A. dufresnii.

Ethical statement: authors declare that they all agree with this publication and made significant contributions; that there is no conflict of interest of any kind; and that we followed all pertinent ethical and legal procedures and requirements. All financial sources are 
fully and clearly stated in the acknowledgements section. A signed document has been filed in the journal archives.

\section{ACKNOWLEDGMENTS}

We are grateful to the diver Ricardo Bebo Vera for the collection of the sea urchins, to Mariano Moris, for helping with the experiments, and to Kathleen C. Anderson for the revision of the English. This work was done with funds from PIP 0352/14, PICT 2018-1729. The sea urchins were collected on the basis of the Provincial Permit $\mathrm{N}^{\circ} 586 / 18$. The first author has a PhD Scholarship from CONICET and Chubut Province.

\section{RESUMEN}

\section{Fotoperiodo en la acuicultura del erizo de mar Arbacia dufresnii (Echinodermata: Echinoidea): El efecto en la producción y madurez de gametas}

Introducción: El fotoperiodo es, junto con la temperatura y la disponibilidad de alimentos, uno de los principales estímulos para el desarrollo de la gametogénesis en una amplia variedad de especies. Objetivo: Evaluar el efecto del fotoperiodo en la producción de gametas maduras de Arbacia dufresnii en un sistema de recirculación cerrado para determinar el mejor fotoperiodo para una acuicultura novedosa, enfocada en la producción de gametas con alta concentración de pigmentos para usos biotecnológicos. Métodos: Se realizó un experimento con tres regímenes/ tratamientos diferentes de luz y oscuridad: luz constante (luz durante $24 \mathrm{~h}$ ), fotoperiodo neutro ( $12 \mathrm{~h}$ de luz, $12 \mathrm{~h}$ de oscuridad) y oscuridad constante (oscuridad durante $24 \mathrm{~h}$ ). Se utilizaron veinte hembras en cada tratamiento. Se indujo a todas las hembras a desovar al comienzo del experimento. Después de 30 días, diez hembras seleccionadas al azar de cada tratamiento fueron inducidas a desovar nuevamente. Al final del experimento, después de 60 días, se indujo el desove a las hembras restantes en cada tratamiento. Las gametas se recolectaron en agua de mar filtrada, se fijaron en solución de Davidson, se cuantificaron y midieron por triplicado en una cámara Sedgewick-Rafter. Para determinar la maduración, se evaluó el éxito de la fecundación después de 30 minutos de fertilización, calculando el porcentaje de huevos fertilizados. Resultados: Nuestros resultados muestran que, en el sistema acuícola, en solo dos meses se obtuvieron gametas maduras y casi 10 veces más la cantidad producida por los erizos de mar en su ambiente natural usando el fotoperiodo neutro (12 h luz:12 h oscuridad). También encontramos que la mayor exposición a la luz produce la menor cantidad de gametas maduras. Conclusión: Este estudio sugiere la viabilidad de la producción de gametos maduros en un corto período de tiempo en Arbacia dufresnii.

Palabras clave: productividad gonadal; equinodermo; equinoideo; acuacultura; gametas maduras.

\section{REFERENCES}

Anderson, M.J., Gorley, R.N., \& Clarke, K.R. (2008). PERMANOVA+ for PRIMER: Guide to software and statistical methods. Plymouth, United Kingdom: Primer_E Ltd.

Bay-Schmith, E., \& Pearse, J.S. (1987). Effect of fixed daylengths on the photoperiodic regulation of gametogenesis in the sea urchin Strongylocentrotus purpuratus. International Journal of Invertebrate Reproduction and Development, 11(3), 287-294.

Brogger, M.I., Martinez, M.I., \& Penchaszadeh, P.E. (2010). Reproduction of the sea urchin Arbacia dufresnii (Echinoidea: Arbaciidae) from Golfo Nuevo, Argentina. Journal of the Marine Biological Association of the United Kingdom, 90(7), 1405-1409.

Brogger, M., Gil, D.G., Rubilar, T., Martinez, M., Díaz de Vivar, M.E., Escolar, M., Epherra, L., Pérez, A., \& Tablado, A. (2013). Echinoderms from Argentina: Biodiversity, distribution and current state of knowledge. In J.J. Alvarado \& F. Solís-Marín (Eds.), Echinoderm Research and Diversity in Latin America (pp. 359-402). Berlín, Heidelberg: Springer-Verlag.

Bromage, N., Porter, M., \& Randall, C. (2001). The environmental regulation of maturation in farmed finfish with special reference to the role of photoperiod and melatonin. Aquaculture, 197, 63-98.

Byrne, M. (1990). Annual reproductive cycle of the commercial sea urchin Paracentrotus lividus from an exposed intertidal and a sheltered subtidal habitat on the west coast of Ireland. Marine Biology, 104, 275-289.

Cárcamo, P. (2004). Massive production of larvae and seeds of the sea urchin Loxechinus albus. In J.M. Lawrence \& O. Guzmán (Eds.), Sea urchins: Fisheries and Ecology (pp. 299-306). Lancaster: DEStech Publications Inc.

Devauchelle, N., \& Mingant, C. (1991). Review of the reproductive physiology of the scallop, Pecten maximus, applicable to intensive aquaculture. Aquatic Living Resources, 4(1), 41-51.

Díaz-Martínez J.P., Carpizo-Ituarte, E.J., \& Benítez-Villalobos, F. (2019). Reproductive patterns of the black starry sea urchin Arbacia stellata in Punta Banda, Baja California, Mexico. Journal of the Marine 
Biological Association of the United Kingdom, 99(6), 1379-1391.

Epherra, L., Gil, D.G., Rubilar, T., Perez-Gallo, S., Reartes, M.B., \& Tolosano, J.A. (2014). Temporal and spatial differences in the reproductive biology of the sea urchin Arbacia dufresnii. Marine and Freshwater Research, 66, 329-342.

Fernández, J.P., Epherra, L., Sepúlveda, L., \& Rubilar, T. (2019). Desarrollo embrionario y larval del erizo de mar verde Arbacia dufresnii. Naturalia Patagónica, 14, 44-58.

Fuji, A. (1967). Ecological studies on the growth and food consumption of Japanese common littoral sea urchin, Strongylocentrotus intermedius (A. Agassiz). Memoirs of the Faculty of Fisheries Hokkaido University, 15(2), 83-160.

Gianguzza, P., \& Bonaviri, C. (2013). Arbacia. In J.M. Lawrence (Ed.), Developments in Aquaculture and Fisheries Science (Vol. 38, pp. 275-283). Amsterdam: Elsevier.

Harris, L.G., \& Eddy, S.D. (2015). Sea urchin ecology and biology. Echinoderm Aquaculture, 1-24.

James, P., Siikavuopio, S.I., \& Mortensen, A. (2015). Sea urchin aquaculture in Norway. Echinoderm Aquaculture, 147-173.

Kelly, M.S. (2001) Environmental parameters controlling gametogenesis in the echinoid Psammechinus miliaris. Journal of Experimental Marine Biology and Ecology, 266(1), 67-80.

Kelly, M., Carboni, S., Cook, E., \& Hughes, A. (2015). Sea urchin aquaculture in Scotland. Echinoderm Aquaculture, 211-224.

Kirchhoff, N., Eddy, S., \& Brown, N. (2010) Out-of-season gamete production in Strongylocentrotus droebachiensis: Photoperiod and temperature manipulation. Aquaculture, 303(1-4), 77-85.

Costa-Leal, M., Rocha, R.J.M., Rosa, R., \& Calado, R. (2016). Aquaculture of marine non-food organisms: What, why and how? Reviews in Aquaculture, 10(2), 400-423.

Liu, H., \& Chang, Y.Q. (2015). Sea urchin aquaculture in China. Echinoderm Aquaculture, 127-146.

Marzinelli, E.M., Bigatti, G., Giménez, J., \& Penchaszadeh, P.E. (2006). Reproduction of the sea urchin Pseudechinus magellanicus (Echinoidea: Temnopleuridae) from Golfo Nuevo, Argentina. Bulletin of Marine Science, 79(1), 127-136.

McCarron, E., Burnell, G., \& Mouzakitis, G. (2010). An experimental assessment on the effects of photoperiod treatments on the somatic and gonadal growth of the juvenile European purple sea urchin Paracentrotus lividus. Aquaculture Research, 41, 1072-1081.

McClintock, J.B., \& Watts, S.A. (1990). The effects of photoperiod on gametogenesis in the tropical sea urchin Eucidaris tribuloides (Lamarck) (Echinodermata: Echinoidea). Journal of Experimental Marine Biology and Ecology, 139(3), 175-184.

Meidel, S.K., \& Scheibling, R.E. (1998) Annual reproductive cycle of the green sea urchin, Strongylocentrotus droebachiensis, in differing habitats in Nova Scotia, Canada. Marine Biology, 131, 461-478.

Mercier, A., \& Hamel, J.F. (2009). Endogenous and exogenous control of gametogenesis and spawning in echinoderms. Advances in Marine Biology, 55, 1-302.

Musgrove, R.J.B. (2005). Aquaculture and Diet Development Subprogram: Postharvest Enhancement of Sea Urchin Roe for the Japanese Market. Australia: FRDC Project 99/319, SARDI Aquatic Sciences Publication No. RD03/0102.

Pearce, C.M., Daggett, T.L., \& Robinson, S.M.C. (2002). Optimizing prepared feed ration for gonad production of the green sea urchin Strongylocentrotus droebachiensis. Journal of the World Aquaculture Society, 33(3), 268-277.

Pearce, C.M., Daggett, T.L., \& Robinson, S.M. (2004). Effect of urchin size and diet on gonad yield and quality in the green sea urchin. Aquaculture, 223(14), 337-367.

Pearse, J.S., \& Eernisse, D.J. (1982). Photoperiodic regulation of gametogenesis and gonadal growth in the sea star Pisaster ochraceus. Marine Biology, 67, 121-125.

Pearse, J.S., \& Walker, C.W. (1986). Photoperiodic regulation of gametogenesis in a North Atlantic sea star, Asterias vulgaris. International Journal of Invertebrate Reproduction and Development, 9, 71-77.

Pérez, A.F., Boy, C., Morriconi, E., \& Calvo, J. (2010). Reproductive cycle and reproductive output of the sea urchin Loxechinus albus (Echinodermata: Echinoidea) from Beagle Channel, Tierra del Fuego, Argentina. Polar Biology, 33(3), 271-280.

Rubilar, T., Epherra, L., Deias-Spreng, J., Díaz De Vivar, M.E., Avaro, M., Lawrence, A.L., \& Lawrence, J.M. (2016). Ingestion, absorption and assimilation efficiencies, and production in the sea urchin Arbacia dufresnii fed a formulated feed. Journal of Shellfish Research, 35(4), 1083-1093.

Spirlet, C., Grosjean, P., \& Jangoux, M. (2000). Optimization of gonad growth by manipulation of temperature and photoperiod in cultivated sea urchins, Paracentrotus lividus (Lamarck) (Echinodermata). Aquaculture, 185(1-2), 85-99. 
Strathmann, R. (1987). Echinoderm larval ecology viewed from the egg. Echinoderm Studies, 2, 55-136.

Unuma, T., Konishi, K., Furuita, H., Yamamoto, T., \& Akiyama, T. (1996). Seasonal changes in gonad of cultured and wild red sea urchin Pseudocentrotus depressus. Suisanzoshoku, 44(2), 169-175.

Unuma, T. (2002). Gonadal growth and its relationship to aquaculture in sea urchins. In Y. Yokota, V. Matranga, \& Z. Smolenicka (Eds.), The Sea Urchin: From Basic Biology to Aquaculture (pp. 115-127). Rotterdam: A.A. Balkema Publishers.

Unuma, T. \& Walker, C.W. (2010). The role of the major yolk protein in sea urchin reproduction and its relevance to aquaculture. In L. Harris, S.A. Böttger, C.W. Walker, \& M.P. Lesser (Eds.), Echinoderms: Durham (pp. 437-444). London: Taylor and Francis Group.

Unuma, T., Sakai, Y., Agatsuma, Y., \& Kayaba, T. (2015). Sea urchin aquaculture in Japan. Echinoderm Aquaculture, $77-126$.

Vaïtilingon, D., \& Williamson, J.E. (2008). WIPO Patent No. WO/2008/074084. Geneva, Switzerland: World Intellectual Property Organization.
Wangensteen, O.S., Turon, X., Casso, M., \& Palacín, C. (2013). The reproductive cycle of the sea urchin Arbacia lixula in northwest Mediterranean: potential influence of temperature and photoperiod. Marine Biology, 160(12), 3157-3168.

Walker, C.W., \& Lesser, M.P. (1998). Manipulation of food and photoperiod promotes out-of-season gametogenesis in the green sea urchin, Strongylocentrotus droebachiensis: implications for aquaculture. Marine Biology, 132, 663-676.

Walker, C.W., Lesser, M.P., \& Unuma, T. (2013). Sea urchin gametogenesis-structural, functional and molecular/genomic biology. In: C.A. Lawrence (Ed.), Sea urchins: Biology and ecology (Vol. 3, pp. 25-44). San Diego: Elsevier Academic Press.

Walker, C.W., Böttger, S.A., Unuma, T., Watts, S.A., Harris, L.G., Lawrence, A.L., \& Eddy, S.D. (2015). Enhancing the commercial quality of edible sea urchin gonads-technologies emphasizing nutritive phagocytes. Echinoderm Aquaculture, 263-286.

Watts, S.A., Lawrence, A.L., \& Lawrence, J.M. (2013). Nutrition. In: J.M. Lawrence (Ed.), Sea urchins: Biology and ecology (Vol. 3, pp. 155-169). San Diego: Elsevier Academic Press. 